\title{
The strategy of the Development of Village-Owned Enterprises (BUMDes) - Based Agriculture in the District Juli Bireuen
}

\author{
Teuku Qadarisman; Zakiah; Suyanti Kasimin \\ Master of Agribusiness, Syiah Kuala University, Indonesia \\ http://dx.doi.org/10.18415/ijmmu.v8i8.2820
}

\begin{abstract}
Rural economic development is an important thing to do given the national economic development should start from the village. One of the efforts that can be done to develop the economy of the village is through entrepreneurship village, which can be the strategy in the development and growth of the welfare of the village community. Entrepreneurship village can be developed through the establishment of Badan Usaha Milik Desa (BUMDes). Rural regions that can not be separated from the agricultural sector, with the importance of the role of agricultural sector to the economy of the country, then the business BUMDes needs to be directed or developed with the activities of the agriculture-based businesses. The results obtained from this research is that BUMDes-based agriculture in the Juli District, Bireun District is in quadrant IV (diversify activities). In this quadrant the position of the organization is in the market is very small and the growth rate is low, therefore it is necessary to diversify the business. This position indicates an organization is weak and facing a big challenge. The recommendations of the given strategy is a survival strategy, meaning that the internal conditions of the organization is on the choice of a dilemma. Therefore, organizations are advised to use a defensive strategy, control of the performance of the internal so not getting mired. This strategy is maintained while continuing to attempt to fix themselves.
\end{abstract}

Keyword: BUMDes; Village; Agriculture

\section{Introduction}

Rural economic development is an important thing to do given that the development of the national economy must be at the start of the village. In addition, rural areas are still experiencing the problems of high poverty that 16,31 million or $13.47 \%$, if compared with urban areas, namely 10,27 million with a percentage 7,26\% (BPS Indonesia, 2019). Therefore, one of the government's efforts to overcome the problem of inequality between rural and urban areas that need to carry out the construction of a national pay great attention to the development of the village (Putra, et al., 2013).

Support to the economic development of the village based on the mandate of the Law On Village Number 6 Year 2014 has been reinforced with the published Regulations of the Minister of Village, Development of Disadvantaged Regions, and Transmigration No. 5 of 2015 About the Determination of Priorities for the Use of Village Fund of the Year 2015 which states that the village fund should be 
prioritized to finance spending on development and empowerment of village communities according to the agreement in the deliberation of the village (the Minister of the Village Minister of Village, Development of Disadvantaged Regions, and Transmigration, 2015). With the priority of the funds of the village, each village should undertake the construction of the village of one of them through the development potential of the local economy. One of the efforts that can be done to develop the economy of the village, namely through the entrepreneurship of the village, which can be the strategy in the development and growth of the welfare of the village community (Ansari, 2016). Then Prabowo (2014), adding that the entrepreneurship village can be developed through the establishment of Village-Owned Enterprises (BUMDes).

The type of business conducted by BUMDes is very diverse ranging from savings and loans, leasing assets of the village, waste management, clean water, and efforts in the field of agriculture (DPMD KSB, 2018). The establishment and development of BUMDes not be separated from efforts to accelerate the program of rural development and community empowerment village in Bireuen. Despite this BUMDesBUMDes contained in Bireuen, especially BUMDes engaged in the agriculture-based businesses are still experiencing difficulties in running and developing a business.

As the district has an agricultural region that vast, Bireuen, should pay more attention to the BUMDes engaged in the agriculture-based businesses are still having a lot of problems in the run and develop their business. Because the villages in this district have a pretty big chance in the run BUMDes shaped agribusiness because it has a very good potential. According to Anggraeni (2016), there are some obstacles and problems in the running of BUMDes is a mistake in the identification of potential with the selection of the type of business, lack of human resource capacity and the making of the accountability report that is still not good. In order to become a driving force of the economy of the community, BUMDes in the District of Bireuen require the innovation and development strategy. The government of KabupatenBireuen and BUMDes manager must implement an effective strategy in order to improve services BUMDes to masyrarakat by leveraging the power of the internal factors which are the opportunities and strength by considering the influence of the external form of threats and weaknesses in the development of BUMDes.

\section{Methodology}

Methods of data analysis used in this research is the analysis of SWOT. The results of this study in addition to will be analyzed using the SWOT analysis also uses a qualitative descriptive analysis method in the translation of the result.Tahapan dalam Analisis SWOT .

\section{a. IFAS Matrix (Internal Factor Analysis Summary)}

After factors-internal strategic factors of a company are identified, a table of IFAS (Internal Factor Analysis Summary) is compiled to formulate strategic factors such internal within the framework of the strength and weakness of the company. Stages are:

1. Determine the factors that become the strength and weaknesses of the company in a column.

2. Give the weight of each factor with a scale ranging from 1.0 (most important) to 0.0 (not important), based on the influence of these factors on the strategic position of the company. (All weights of such amount does not exceed the total score of 1.00).

3. Give rating 1 to 4 for each factor to indicate whether these factors have a great weakness (rating $=$ 1 ), the weakness of the small (rating $=2$ ), a small strength (rating $=3$ ), and great strength (rating= 4). So actually, the rating refers to the company whereas weight refers to the industry where the company is located.

4. Multiply each weight with his ratings to get a score.

5. Add up the total score of each variable. 
Regardless of the number of factors included in the matrix IFAS, the total weighted average ranged from a low of 1.0 and the highest is 4.0 with an average of 2.5. If the average total under 2.5 indicates that the company's internal weak, while the total value above 2.5 to indicate the position of the internal strong.

\section{b. EFAS Matrix (Eksternal Factor Analysis Summary)}

1) There are five stages of the preparation of the matrix factors of the strategy of the external :

2) 1) Determine the factors into opportunities and threats.

3) 2) Give the weight of each factor from 1.0 (very important) to 0.0 (not important). Factors that may impact on the strategic factors. Sum of all weights should be equal to 1.0.

4) 3) Calculate the rating for each factor by giving the scale from 1 to 4 , where 4 (the response is very good), 3 (response to above-average), 2 (average response), 1 (response below the average). This Rating is based on the effectiveness of the company's strategy, thus its value based on the condition of the company.

5) 4) Multiply each weight, with his ratings to get a score.

6) 5) Add up all the scores to get the total score of the company. the total value of this demonstrates how a specific company reacts to the strategic factors external.

\section{c. SWOT Matrix}

A SWOT matrix is a tool-a tool that is used to measure the factors of strategy of the company. This matrix can describe clearly how the opportunities and external threats owned.

\section{d. SWOT Diagram}

The next step is to study through the diagram SWOT analysis to make the point of intersection between the $\mathrm{X}$ axis and the $\mathrm{Y}$-axis, where the value of the $\mathrm{X}$-axis obtained from the difference between the total strength and total weakness, while for the $\mathrm{Y}$ axis value obtained from the difference between the total opportunities and total threat.

\section{Result and Discussion}

The analysis of external and internal factors is done by knowing the factors on the outside and inside of BUMDes-based agriculture in the District July Bireun District that can affect the development of BUMDes such. Analysis of internal factors used to analyze the internal factors that will certainly affect the development of BUMDes-based agriculture in the District July Bireun District. Internal factors can be identified as strengths and weaknesses for the development of the BUMDes, while the analysis of external factors is done by looking at factors outside of BUMDes to identify and evaluate trends that are beyond the control. This analysis is focused to obtain the key factors that become opportunities and threats for the development of BUMDes-based agriculture in the District July Bireun District, making it easier to determine strategies to seize opportunities and avoid threats. 
Tabel 1. Analisis SWOT pada BUMDes di Kecamatan Juli Kabupaten Bireun

\begin{tabular}{|c|c|}
\hline $\begin{array}{l}\text { Strength } \\
\text { 1. Regulation on guidelines for the establishment } \\
\text { and management of village-owned enterprises. } \\
\text { 2. The number of HUMAN resources are sufficient. } \\
\text { 3. Capital BUMDes available in sufficient } \\
\text { quantities. }\end{array}$ & $\begin{array}{l}\text { Weakness } \\
\text { 1. The management of BUMDes, yet } \\
\text { professional. } \\
\text { 2. The quality of HUMAN resources is still } \\
\text { low. } \\
\text { 3. Infrastructure and means of BUMDes is not } \\
\text { maximized. } \\
\text { 4. The still high mortality of livestock } \\
\text { cultivated by BUMDes. }\end{array}$ \\
\hline $\begin{array}{l}\text { Opportunity } \\
\text { 1. Most people are farmers. } \\
\text { 2. There is a potential business BUMDes other in } \\
\text { addition to the savings and loan is in the form of } \\
\text { sales facilities and infrastructure, agricultural } \\
\text { and non-agricultural. } \\
\text { 3. Opportunities for cooperation with various } \\
\text { stakeholders in the development of BUMDes. }\end{array}$ & $\begin{array}{l}\text { Treat } \\
\text { 1. Awareness of the public to take advantage } \\
\text { of BUMDes is still lacking. } \\
\text { 2. The presence of price competition with } \\
\text { other parties. } \\
\text { 3. The access road to the BUMDes is still } \\
\text { difficult making it difficult for people and } \\
\text { parties BUMDes to interact with each other. }\end{array}$ \\
\hline
\end{tabular}

a. IFAS Matrix (Internal Factor Analysis Summary)

After factors-internal strategic factors a BUMDes identified, a table of IFAS (Internal Factor Analysis Summary) is compiled to formulate strategic factors such internal within the framework of the strength and weakness of BUMDes.

Tabel 2. IFAS Matrix (Internal Fatcor Analysis Summary)

\begin{tabular}{|c|c|c|c|c|}
\hline No. & Internal Factors & Weight & Rating & Score \\
\hline \multicolumn{5}{|c|}{ Strength } \\
\hline 1. & $\begin{array}{l}\text { Regulation on guidelines for the establishment and management of } \\
\text { village-owned enterprises. }\end{array}$ & 0.20 & 4 & 0.80 \\
\hline 2. & The number of HUMAN resources are sufficient. & 0.10 & 3 & 0.30 \\
\hline 3. & Capital BUMDes available in sufficient quantities. & 0.17 & 4 & 0.68 \\
\hline \multicolumn{2}{|r|}{ Subtotal } & 0.47 & & 1.78 \\
\hline \multicolumn{5}{|c|}{ Weakness } \\
\hline 1. & $\begin{array}{l}\text { There is still a high failure rate of businesses run by BUMDes, such } \\
\text { as dead livestock. }\end{array}$ & 0.17 & 4 & 0.68 \\
\hline 2. & The quality of HUMAN resources is still low & 0.14 & 3 & 0.42 \\
\hline 3. & Infrastructure and means of BUMDes is not maximized. & 0.10 & 2 & 0.20 \\
\hline 4. & The management of BUMDes, yet professional. & 0.12 & 3 & 0.36 \\
\hline \multirow{2}{*}{\multicolumn{2}{|c|}{ Subtotal }} & 0.53 & & 1.66 \\
\hline & & 1.00 & & 3.44 \\
\hline
\end{tabular}

The table above, the factors of strength and weakness have a total score 3.44. Because the total score above the 2.5 means it indicates the position of the internal on BUMDes-based agriculture in the District July Bireun District so strong.

\section{b. EFAS Matrix (External Factor Analysis Summary)}

After the strategic factors external to a BUMDes identified, a table of EFAS (External Factor Analysis Summary) is compiled to formulate strategic factors such external within the framework of the opportunity and threat. 
Table 3. EFAS Matrix (External Factor Analysis Summary)

\begin{tabular}{|c|c|c|c|c|}
\hline No. & Exsternal Factors & Weight & Rating & Score \\
\hline \multicolumn{5}{|c|}{ Oppurtunity } \\
\hline 1. & Most people are farmers. & 0.18 & 4 & 0.72 \\
\hline 2. & $\begin{array}{l}\text { There is a potential business BUMDes other in addition to the savings } \\
\text { and loan is in the form of sales facilities and infrastructure, } \\
\text { agricultural and non-agricultural. }\end{array}$ & 0.16 & 3 & 0.48 \\
\hline 3. & $\begin{array}{l}\text { Opportunities for cooperation with various stakeholders in the } \\
\text { development of BUMDes. }\end{array}$ & 0.10 & 2 & 0.20 \\
\hline & Subtotal & 0.44 & & 1.40 \\
\hline \multicolumn{5}{|c|}{ Threat } \\
\hline 1. & $\begin{array}{l}\text { Awareness of the public to take advantage of BUMDes is still } \\
\text { lacking. }\end{array}$ & 0.16 & 4 & 0.64 \\
\hline 2. & The presence of price competition with other parties. & 0.15 & 3 & 0.45 \\
\hline 3. & $\begin{array}{l}\text { The access road to the BUMDes is still difficult making it difficult for } \\
\text { people and parties BUMDes to interact with each other. }\end{array}$ & 0.10 & 2 & 0.20 \\
\hline 4. & $\begin{array}{l}\text { Awareness of the public to take advantage of BUMDes is still } \\
\text { lacking. }\end{array}$ & 0.15 & 4 & 0.60 \\
\hline \multicolumn{2}{|r|}{ Subtotal } & 0.56 & & 1.89 \\
\hline \multicolumn{2}{|r|}{ Total } & 1.00 & & 3.29 \\
\hline
\end{tabular}

From the results of the analysis in the table above, the factors the opportunities and threats have a total score of 3.34. Because the total score approach 4.0 means this indicates that BUMDes-based agriculture in the District July Kabupaten Bireun respond to the opportunities that exist in a remarkable way and avoid threats in the market industry. Furthermore, the value of the total score of each factor can be specified, strength 1.78; weakness 1.66; opportunity 1.40 ; threat 1.89 . Then be aware the difference between the total scores of the factors of strength and weakness is (+) 0.12 , while the difference between the total factor scores oppurtunity and the threat is (-) 0.49 .

Below is a picture diagram of the cartesian diving SWOT Analysis BUMDes-based agriculture in the District July of Bireun District:

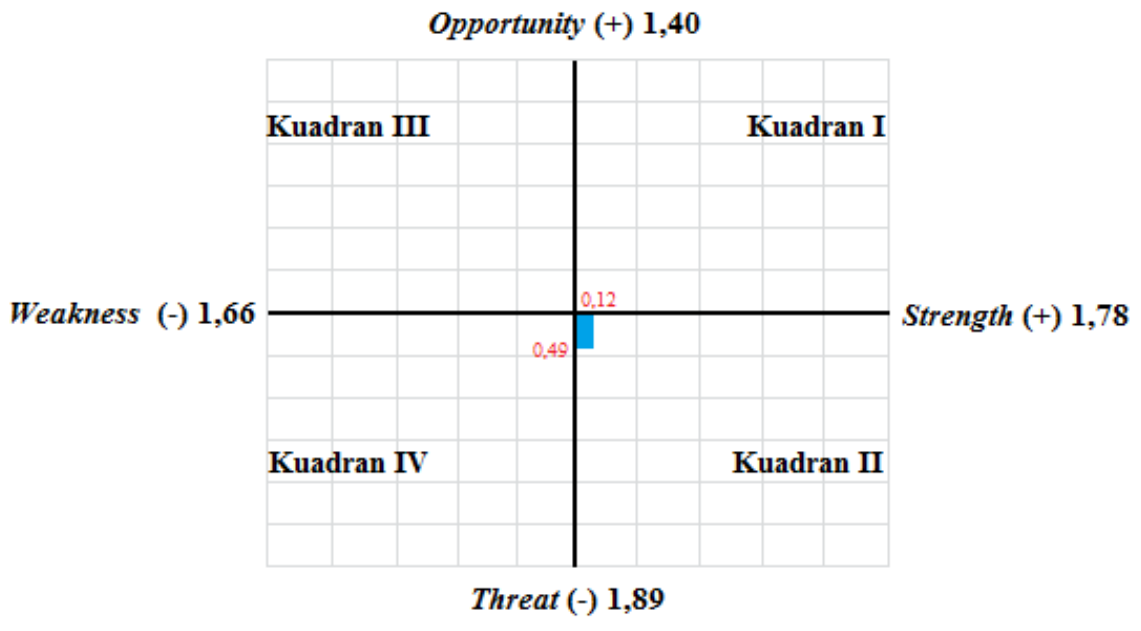

Gambar 2. Cartesius DiagramSWOT Analysis

From a picture diagram of the cartesian diving above, shows that BUMDes-based agriculture in the District July Kabupaten Bireun is in quadrant IV (diversify activities). In this quadrant the position of the organization is in the market is very small and the growth rate is low so it needs to be done to diversify the business. This position indicates an organization that is weak and facing a big challenge. The 
recommendations of the given strategy is a survival Strategy, meaning that the internal conditions of the organization is on the choice of a dilemma. Therefore, organizations are advised to meenggunakan survival strategy, controlling the performance of the internal so not getting mired. This strategy is maintained while continuing to attempt to fix themselves.

\section{c. SWOT Matrix}

A SWOT matrix is a tool which is used to measure the factors of strategy of BUMDes. This matrix can describe clearly how the opportunities and external threats owned. This matrix can produce four cells the possibility of an alternative strategy that can be seen in the table below:

Table 4. SWOT Matrix

\begin{tabular}{|c|c|c|}
\hline EFAS & $\begin{array}{l}\text { Strength (S) } \\
\text { 1. Regulation on guidelines } \\
\text { for the establishment and } \\
\text { management of village- } \\
\text { owned enterprises. } \\
\text { 2. The number of HUMAN } \\
\text { resources are sufficient. } \\
\text { 3. Capital BUMDes available } \\
\text { in sufficient quantities. }\end{array}$ & $\begin{array}{l}\text { Weakness }(\mathbf{W}) \\
\text { 1. The management of } \\
\text { BUMDes, yet professional. } \\
\text { 2. The quality of HUMAN } \\
\text { resources is still low. } \\
\text { 3. Infrastructure and means of } \\
\text { BUMDes is not maximized. } \\
\text { 4. The still high mortality of } \\
\text { livestock cultivated by } \\
\text { BUMDes. }\end{array}$ \\
\hline $\begin{array}{l}\text { Oppurtunity (O) } \\
\text { 1. Most people are farmers. } \\
\text { 2. There is a potential } \\
\text { business BUMDes other } \\
\text { in addition to the savings } \\
\text { and loan is in the form of } \\
\text { sales facilities and } \\
\text { infrastructure, agricultural } \\
\text { and non-agricultural. } \\
\text { 3. Opportunities for } \\
\text { cooperation with various } \\
\text { stakeholders in the } \\
\text { developmentof BUMDes. }\end{array}$ & $\begin{array}{l}\text { Strategi S-O } \\
\text { - Optimize the program of } \\
\text { financing the system of } \\
\text { farming by increasing the } \\
\text { amount of the loan society, } \\
\text { especially farmers given the } \\
\text { capital requirements of } \\
\text { farming needed by the } \\
\text { community is very high. } \\
\text { - In addition to the financing, } \\
\text { BUMDes can do business in } \\
\text { the sale of agricultural inputs } \\
\text { required by farmers, for } \\
\text { example seeds, medicines, } \\
\text { fertilizers, agricultural tools, } \\
\text { and so forth either by way of } \\
\text { cash or credit. } \\
\text { BUMDes can facilitate the } \\
\text { development of group or } \\
\text { institutional specific instance } \\
\text { with the help of the farmers } \\
\text { distribute their agricultural or } \\
\text { establish cooperation with } \\
\text { related parties in providing } \\
\text { animal sacrifices. }\end{array}$ & $\begin{array}{l}\text { Strategi S-T } \\
\text { - Improve the professional } \\
\text { management of BUMDes } \\
\text { through a variety of education } \\
\text { and training of HUMAN } \\
\text { resources. } \\
\text { - Increase cooperation with } \\
\text { related parties in reducing the } \\
\text { risk of default due to crop } \\
\text { failure for example with } \\
\text { insurance agencies that can } \\
\text { facilitate insurance, especially } \\
\text { for farmers. } \\
\text { - Improvement of facilities and } \\
\text { infrastructure } \\
\text { especially the offices and } \\
\text { other auxiliary equipment that } \\
\text { are not available so facilitate } \\
\text { employees of BUMDes in the } \\
\text { work and add to the } \\
\text { attractiveness of the } \\
\text { community to trade in } \\
\text { BUMDes. }\end{array}$ \\
\hline $\begin{array}{l}\text { Threat }(\mathbf{T}) \\
\text { 1. Awareness of the public to } \\
\text { take advantage of } \\
\text { BUMDes is still lacking. }\end{array}$ & $\begin{array}{l}\text { Strategi S-T } \\
\text { - Highlight the advantages, the } \\
\text { convenience and security of } \\
\text { transacting in BUMDes. }\end{array}$ & $\begin{array}{l}\text { Strategi W-O } \\
\text { - Strengthen cooperation with } \\
\text { relevant parties, especially the } \\
\text { government to provide a } \\
\text { stimulant to the BUMDes so }\end{array}$ \\
\hline
\end{tabular}




\begin{tabular}{|c|c|c|}
\hline $\begin{array}{l}\text { 2. The presence of price } \\
\text { competition with other } \\
\text { parties. } \\
\text { 3. The access road to the } \\
\text { BUMDes is still difficult } \\
\text { making it difficult for } \\
\text { people and parties } \\
\text { BUMDes to interact with } \\
\text { each other. }\end{array}$ & $\begin{array}{l}\text { - Provide education and } \\
\text { guidance to the public about } \\
\text { the importance of Air- } \\
\text { BUMDes. } \\
\text { - Enhance cooperation with the } \\
\text { government especially the } \\
\text { Department of Cooperatives, } \\
\text { Trade and SMES with the } \\
\text { involvement of BUMDes in a } \\
\text { variety of event area so that } \\
\text { more people know BUMDes. }\end{array}$ & $\begin{array}{l}\text { as to compete with other } \\
\text { financial institutions. } \\
\text { - Created a business unit that is } \\
\text { not run by the competitor. } \\
\text { - Establish the association of } \\
\text { BUMDes up to the district } \\
\text { level in order to share } \\
\text { information and experiences } \\
\text { related to the development of } \\
\text { BUMDes in each region. } \\
\text { - Provide training to the } \\
\text { management of BUMDes to } \\
\text { explore the areas in which } \\
\text { they live. }\end{array}$ \\
\hline
\end{tabular}

Based on the results of the SWOT analysis above is obtained that in the matrix IFAS shows the factors of strength and weakness have a total score of 3.47. This indicates that the business of BUMDesbased agriculture in the District July Kabupaten Bireun is on the position of the internal so strong. Furthermore, in the matrix, EFAS showed that factors the opportunities and threats have a total score of 3.14. This indicates that the business of BUMDes-based agriculture in the District July Kabupaten Bireun can respond to the opportunities that exist in a remarkable way and avoid the threats that are in the market industry.

As in the diagram cartesian diving shown that BUMDes-based agriculture in the District July Kabupaten Bireun is in quadrant IV (diversify activities). This position indicates an organization that is weak and facing a big challenge. The recommendations of the given strategy is a survival Strategy. Nevertheless, the look is still opportunities to BUMDes grown to be more advanced. With the angel of strength with opportunities or strategies SO, then the obtained factor power must be maintained to be able to take the opportunities that exist. Coupling ST strategy shows that BUMDes should maximize the strength to overcome the threats that exist. WO strategies, take advantage of existing opportunities by minimizing the weaknesses of BUMDes. As well as the strategy of WT which requires BUMDes to be able to minimize weaknesses and avoid threats.

\section{Conclusions and Recommendations}

Internal factors of BUMDes-based agriculture in the District July of Bireun District is a factor of strength (strength) in the form: regulation on guidelines for the establishment and management of villageowned enterprises, the number of HUMAN resources are sufficient, and the capital of BUMDes available in sufficient quantities. And the factor of weakness (weakness) in the form: The Management of BUMDes, yet professional, the quality of HUMAN resources is still low, the infrastructure and the means of BUMDes is not maximized., the access road to the BUMDes is still difficult so often adds to the cost of transportation, the still high mortality of livestock cultivated by BUMDes.

External factors of BUMDes-based agriculture in the District July KabupatenBireun is a factor of the opportunities (opportunity): most of the people are farmers, there is a potential business BUMDes other in addition to the savings and loan is in the form of sales facilities and infrastructure, agricultural and nonagricultural, the chance of cooperation with various related parties in the development of BUMDes. And the factor of threat (threat): the awareness of the community to make use of BUMDes is still lacking, the absence of price competition with other parties. 
BUMDes-based agriculture in the District July Kabupaten Bireun is in quadrant IV (diversify activities). In this quadrant the position of the organization is in the market is very small and the growth rate is low so it needs to be done to diversify the business. This position indicates an organization that is weak and facing a big challenge. The recommendations of the given strategy is a survival Strategy, meaning that the internal conditions of the organization is on the choice of a dilemma. Therefore, organizations are advised to meenggunakan survival strategy, controlling the performance of the internal so not getting mired. This strategy is maintained while continuing to attempt to fix themselves.

\section{References}

Anggreani, M. R. R. S (2016). Peranan Badan usaha Milik Desa (BUMDes) pada Kesejahteraan Masyarakat Pedesaan Studi pada BUMDes di Gunung Kidul Yogyakarta. Jurnal Modus, 28(2), 155-167.

Ansari, B., etal. (2016). Sustainable Entrepreneurship in Rural Areas. Research Journal of Environmental and Earth Science. Vol.5. No.1 :26-31.

BPS Indonesia. 2019. Beritaresmistatistik 2020. Profilkemiskinan Indonesia.

DPMD KSB. (2018). Data ProfilBumdes di Kabupaten Sumbawa Barat Tahun 2018. Sumbawa Barat: Dinas Pemberdayaan Masyarakat dan Desa Kabupaten Sumbawa Barat.

Prabowo, T.H.E. (2014). Developing BUMDes (Village-owned Enterprise) for Sustainable Poverty Alleviation Model Village Community Study in Bleberan-Gunung Kidul- Indonesia. World Applied Sciences Journal 30(Innovation Challengesin Multidiciplinary Research \& Practice): 19-26.

Undang-Undang Republik Indonesia Nomor 6 Tahun 2014 Tentang Desa.

\section{Copyrights}

Copyright for this article is retained by the author(s), with first publication rights granted to the journal.

This is an open-access article distributed under the terms and conditions of the Creative Commons Attribution license (http://creativecommons.org/licenses/by/4.0/). 